\title{
NFC-Aktivitäten in Österreich
}

\author{
K. Lamedschwandner OVE IEEE, M. Bammer
}

Online publiziert am 8. November 2013

(C) Springer Verlag Wien 2013

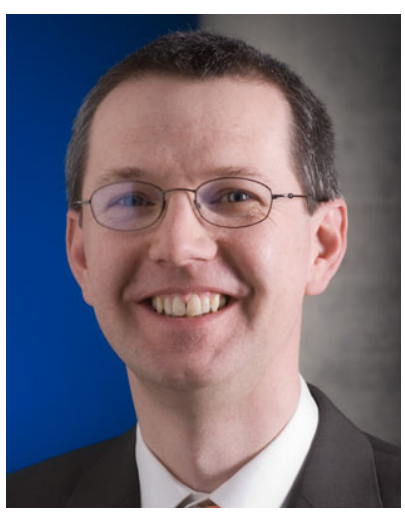

Dipl.-Ing. Dr. Kurt

Lamedschwandner, MBA

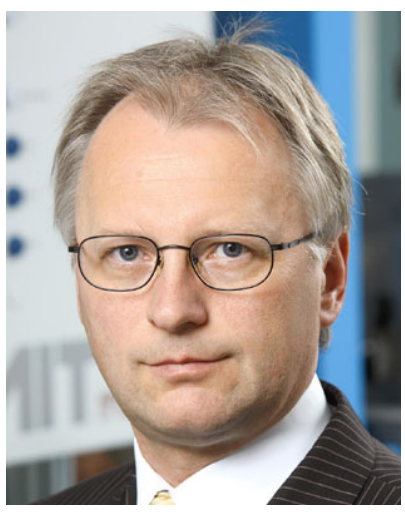

Dipl.-Ing. Manfred Bammer, MAS

Ziel dieser e\&i-Ausgabe ist es, eine wissenschaftlich fundierte Zusammenstellung von aktuell laufenden Entwicklungen auf dem NFC-Gebiet in Österreich zu geben. Darüber hinaus werden auch praxisnahe Anwendungen und Messtechnik-Konzepte für zukünftige Anwendungen vorgestellt.

Wie die eingeworbenen Beiträge zeigen, sind in Österreich beim Thema NFC sehr viele namhafte Player aktiv, was nicht verwunderlich ist, liegt ja auch die "Geburtsstätte" von NFC zumindest teilweise in Österreich, nämlich im steirischen Gratkorn bei Graz (NFC wurde 2002 von den Chipherstellern NXP Semiconductors und Sony erfunden).

Die Beiträge spannen einen breiten Bogen, beginnend bei Antennenentwicklungen und Entwicklungen neuartiger, intelligenter NFC-Sensoren über die Themen der Übertragungsgeschwindigkeiten, Systemarchitekturen bis hin zu Sicherheitsaspekten im "Web der Dinge" und vielen Praxisanwendungen.

Einige besondere Aspekte von NFC im Vergleich zu anderen Kommunikationstechnologien seien hier hervorgehoben, wie die einfache Handhabung von NFC im Zusammenhang mit der Datenerfassung aus elektronischen Geräten. Aber auch die Kombination mit
NFC- kompatiblen Symbolkarten, Tags und Authentifizierungskarten ermöglicht sichere Szenarien bei kritischen Anwendungen, wo Datenschutz und Privatsphäre eine essentielle Rolle spielen (z. B. im Gesundheitswesen). NFC ist die einzige Kommunikationstechnologie, bei der mit einem NFC-Lesegerät (z. B. NFC-fähiges Smartphone) elektronische und nicht-elektronische Daten erfasst werden können. Das wiederum ist für die praktische Anwendung ein entscheidender Usability-Aspekt für alle Altersgruppen.

Darüber hinaus kann mittels NFC auch Energie in so genannte smarte NFC-Sensorlösungen eingekoppelt werden, wodurch einfache und auch relativ komplexe Sensorlösungen in einem teilweise noch nie dagewesenen Miniaturisierungsgrad realisiert werden können. Die Beispiele in den Artikeln werden Sie, liebe Leserin, lieber Leser, teilweise in Staunen versetzen darüber, was zukünftig alles mit NFC möglich sein wird. Wir wollen in diesem Zusammenhang auch den Begriff "NFC-Sensing" einführen, da dieser Begriff ein Synonym für alle aktuellen und zukünftigen smarten NFC-Sensorlösungen sein wird. Mit diesen Sensing-Möglichkeiten von NFC wird ein Mehrwert bei potentiellen Anwendungen geschaffen, der mit keiner anderen derzeit verfügbaren Kommunikationstechnologie (sei es Bluetooth oder QR-Code) auf eine so einfache Art und Weise erreichbar ist. Dadurch sind neue Massenanwendungen im Gesundheitswesen und in anderen Branchen möglich, die NFC endgültig zum Megatrend in der Kommunikations-Community werden lassen.

An dieser Stelle soll der Hinweis nicht fehlen, dass wir bei der nächsten EMV-Fachtagung, die im Frühjahr 2014 am Campus der Seibersdorf Labor GmbH stattfinden wird, wieder einen Parallelworkshop zum Thema NFC-Applikationen planen. Dazu möchten wir Sie schon jetzt sehr herzlich einladen, entweder als Referent/in oder Zuhörer/in. Dort können Sie dann mehr über NFC-Sensing und die aktuellen Möglichkeiten aus praktischer Perspektive erfahren.

Wir wünschen Ihnen viel Vergnügen beim Lesen der Beiträge! Vielleicht ergeben sich dadurch für Sie neue Ideen für Weiterentwicklungen, Anwendungen und Geschäftsmodelle oder Kontakte für zukünftige Kooperationsprojekte.

Abschließend möchten wir uns noch bei den Autoren und bei der e\&i-Redaktion für die ausgezeichnete Zusammenarbeit bedanken!

\section{NFC activities in Austria}

Totally unknown just a few years ago, Near Field Communication (NFC) is now increasingly establishing itself as one of the most promising forward-looking technologies for wireless data exchange over short distances.

Its communication design is remarkably simple and manufacturers are increasingly integrating NFC technology into smartphones and electronic devices. This means that the usability and availability of

Lamedschwandner, Kurt, Seibersdorf Labor GmbH, 2444 Seibersdorf, Österreich (E-Mail: kurt.lamedschwandner@seibersdorf-laboratories.at); Bammer, Manfred, AIT Austrian Institute of Technology GmbH, 2700 Wiener Neustadt, Österreich (E-Mail: manfred.bammer@ait.ac.at) 
this technology are virtually unlimited. It is also compatible with RFID infrastructures operating in the $13.56 \mathrm{MHz}$ frequency band. Many applications for cashless payments, ticketing, marketing, and in the health care and nursing sectors will therefore be made possible by this communication technology in future if not already in place.

The aim of this issue of e\&i is to provide a scientifically accurate compilation of ongoing developments in Austria in the field of NFC technology. Practice-oriented applications and measuring technology concepts for future applications will also be presented.

As demonstrated by the articles we have received, the subject of NFC involves many key players in Austria-hardly surprising given that NFC's "birthplace" is in Austria, namely in the town of Gratkorn near Graz (NFC was invented by chip manufacturers NXP Semiconductors and Sony in 2002).

The articles cover a wide range of topics, starting with antenna developments and the development of new kinds of intelligent NFC sensors, through to the issues of transmission speeds, system architectures, and safety aspects in the "Internet of Things" and many practical applications.

Some unique benefits of NFC in comparison with other communication technologies are worth special mention here, including NFC's easy operation when used to record data from electronic devices. However, the use of NFC-compatible symbol cards, tags, and authentication cards also enables safe scenarios in critical applications, where data protection and privacy play an essential role. This is often the case in the health care sector. NFC is the only communication technology which can be used with an NFC reading device (e.g., an NFC-enabled smartphone) to read electronic and non-electronic data. That, in turn, ensures a key benefit for all age groups in the technology's practical use.

What's more, NFC can be used to feed energy into smart NFC sensor solutions, allowing both simple and relatively complex sensor solutions to be created on a scale of miniaturization that, in some cases, has never been seen before. When you read some of the examples given in the articles, you will be amazed by the possibilities this technology will open up in the future. We want to bring the concept of NFC sensing into the equation since this concept will be synonymous for all smart NFC sensor solutions-both now and in future. These sensing possibilities offered by NFC create an added value for potential applications which no other currently available communication technology_such as Bluetooth or QR codes-could offer so easily. This makes new mass applications possible in the health care sector and also in other industries, thereby establishing NFC as a mega trend in the communication community.

At this point, we should indicate that we are once again planning a workshop on the topic of NFC applications which will run in parallel to the next EMC conference in Spring 2014 on Seibersdorf Labor GmbH's premises. You are warmly invited to attend-either as a speaker or as a listener. This will be an opportunity to learn more about NFC sensing and its current possibilities from a practical perspective.

We hope you enjoy reading the articles and perhaps devise some new ideas for further developments, applications and business models or make some new contacts for joint future projects.

We would like to close by thanking the authors and the e\&i editing team for their excellent cooperation! 